\title{
Stanford animal-research facility expansion hit by local protests
}

\section{San Francisco}

Opposition to research in genetic engineering from environmental and animal rights groups seems likely to slow Stanford University's plans for expansion of its biological sciences facilities. The ground-breaking ceremony for the new $\$ 33$-million building, scheduled for next month, is now under threat following a local group's request for an environmental impact report (EIR) to assess the hazards of recombinant DNA research to be carried out in the building.

The setback comes on the heels of a successful attempt by the local humane society to block construction of the second phase of a \$29-million research animal facility. Construction of the animal facility was scheduled to begin last June. In May, the Palo Alto Humane Society filed an appeal challenging the university's use permit and requested an EIR.

The humane society raised the issue of possible hazardous emissions from the facility, but most of their concerns focus on animal welfare. Stanford argued that the construction of the 'state of the art' animal facility is evidence of their commitment to animal welfare, and provided assurance that the building will meet all current standards for laboratory animal care. Because of the degree of public controversy, the county supervisors nevertheless called for an EIR. Construction has been set back almost a year at a cost to the university of some $\$ 1.5$ million in delays and expenses for the report.

The biological sciences building, part of the Near West Campus project, (see Nature, 329, 281; 1987) has been on the drawing board for nearly 4 years. On 13 August a county planning committee waived the need for an EIR. The Silicon Valley Toxics Coalition filed an appeal on 28 August to reverse the decision. At a meeting on 1 October, the county planning commission heard both sides of the argument, and planned to vote on 5 November. The commission appears to favour Stanford, but the toxics coalition has vowed to appeal their case in the courts if necessary.

The 6-year-old toxics coalition has never before opposed recombinant DNA research, but was alerted to the issue by the Laurel Heights neighbourhood association, which is fighting expansion by the University of California, San Francisco (see Nature 328, 656; 1987). The coalition wants assurances that Stanford will strictly enforce laboratory safety regulations, and that neither harmful levels of radioactivity nor viable recombinant organisms will leave the building.

Stanford claims a good record of com- pliance with safety regulations, and says no hazardous research will go on in either the new or the existing biology buildings.

Stanford officials will decide next week whether to begin an EIR immediately or to continue to defend their position. An EIR could take up to a year and cost
$\$ 500,000$, but a court fight could increase time and cost significantly more.

Stanford spokesman Larry Horton points out that an EIR will provide no new information about the safety of recombinant DNA. Professor Robert Simoni, chairman of the biology department building committee, fears that even a perfect EIR, showing total compliance with safety rules, will be challenged by the groups in their effort to tighten local regulation of facilities.

\section{Cable companies tied up in knots in international Pacific network}

\section{Tokyo}

Two rival international telecommunications companies, International Digital Communications (IDC) and International Telecom Japan (ITJ), have filed separate applications for operating licenses with Japan's Ministry of Post and Telecommunications. Meanwhile, Kokusai Denshin Denwa (KDD), which currently monopolizes Japan's international telecom market, has revealed ambitious plans to lay a network of trans-Pacific optical fibre cables to compete with a cable to be laid by one of the new companies.

When Britain's Cable and Wireless company announced plans last year to form IDC in collaboration with Japanese and US companies, there was considerable opposition to their plan in government and business circles. The Ministry of Post and Telecommunications objected to the British firm having a major say in the management of the com-

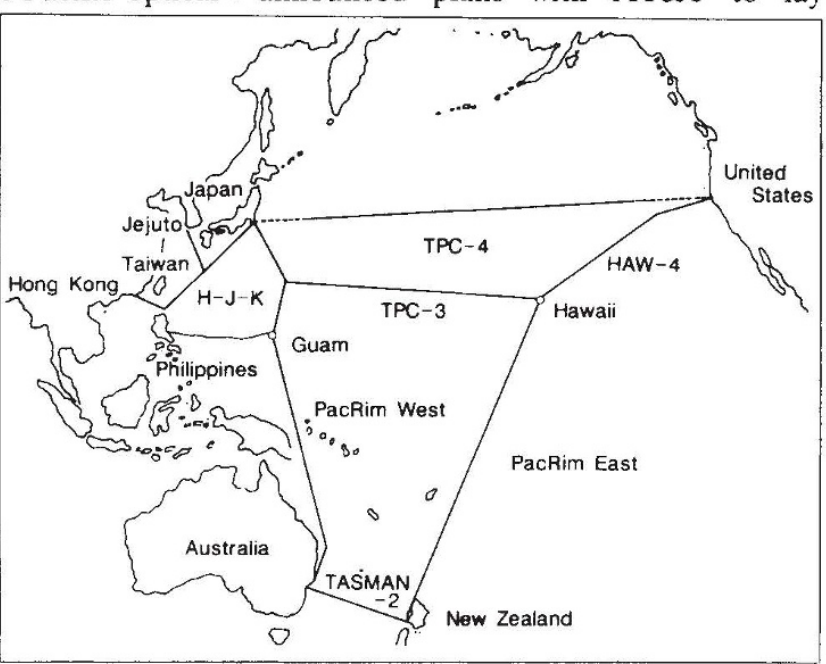
pany and tried to force a Optical fibre cables to be laid by KDD, AT\&T and companies merger with the all- from several other countries. In addition to these cables, Britain's Japanese consortium Cable and Wireless and IDC plan a cable linking Japan and Alaska. ITJ. The ministry and KDD also argued another trans-Pacific cable (TPC-4) direct that there is no need for the trans-Pacific cable which Cable and Wireless intends to lay between Japan and Alaska.

But the exclusion of Cable and Wireless threatened to ignite another major trade dispute with Britain and the United States at a time when the US Congress is compiling an omnibus trade bill, and recently Prime Minister Yasuhiro Nakasone and the ministry agreed to accept a separate license application from IDC and process it in a "fair and transparent manner" (see Nature 328, 563; 1987).

IDC and ITJ plan to begin services in 1989 and offer rates $20-30$ per cent lower than KDD. Both will use Intelstat satellites, but, whereas ITJ will plug into the
trans-Pacific cable network to be laid by KDD, American Telephone and Telegraph (AT\&T) and telecommunications companies from several other countries, IDC will lay its own North Pacific cable in 1989-90 that will short-circuit KDD and AT\&T's trans-Pacific cable (TPC-3), due to be completed next year, by $5,000 \mathrm{~km}$.

In response, $\mathrm{KDD}$, which initially argued that Cable and Wireless's cable would result in overcapacity, has announced plans with AT\&T to lay to the United States that will be operational in 1994. In has also agreed with Australian and New Zealand companies to lay a gigantic $16,000-\mathrm{km}$ loop of cables linking Guam, Australia, New Zealand and Hawaii to the the TPC-3 cable.

The KDD/AT\&T trans-Pacific cables will cost more than $\$ 1,000$ million, excluding TPC-4, the cost of which has yet to be announced, compared with $\$ 400$ million for Cable and Wireless's $8,000-\mathrm{km}$ cable.

The Ministry of Post and Telecommunications fears that the large number of cables will lead to overcapacity and excessive competition. But Sir Eric Sharp, chairman of Cable and Wireless, says they will create more demand. David Swinbanks 